\title{
Preparation of nano-crystalline tungsten powders from gaseous $\mathrm{WO}_{2}(\mathrm{OH})_{2}$
}

\author{
Markus Ostermann ${ }^{1} \cdot$ Valentin Dalbauer $^{1} \cdot$ Wolf-Dieter Schubert ${ }^{1} \cdot$ Roland Haubner $^{1}$ (I)
}

Received: 8 June 2021 / Revised: 5 July 2021 / Accepted: 7 July 2021 / Published online: 18 October 2021

(c) The Author(s) 2021

\begin{abstract}
The industrial production of tungsten powder is carried out by the reduction of tungsten oxide powder via hydrogen. In this process, the size of the $\mathrm{W}$ particles is limited to particle sizes larger than $100 \mathrm{~nm}$. To get below this limit, alternative processes are needed. In the current work, the possibility of preparing $\mathrm{W}$ powder below $100 \mathrm{~nm}$ via a vapour phase reduction of volatile $\mathrm{WO}_{2}(\mathrm{OH})_{2}$ by hydrogen was investigated. The process consists of two stages. In the first stag,e $\mathrm{WO}_{2}(\mathrm{OH})_{2}$ is formed by reacting $\mathrm{WO}_{3}$ with water vapour at temperatures of $1000-1100{ }^{\circ} \mathrm{C}$. In the second stage, $\mathrm{WO}_{2}(\mathrm{OH})_{2}$ is reduced by hydrogen at about $1000^{\circ} \mathrm{C}$ to form metallic tungsten. The influence of process parameters such as furnace temperature, humidity and gas flow on the $\mathrm{WO}_{2}(\mathrm{OH})_{2}$ evaporation and formation of tungsten powder was investigated. The characterization of the resulting powders was performed by X-ray diffraction (XRD), field emission scanning electron microscopy (FE-SEM) and transmission electron microscopy (TEM). By optimization of the reaction conditions, powder with a metallic tungsten content of about 70 at \% besides tungsten oxides was produced with metal particle sizes down to $5 \mathrm{~nm}$. Further optimization should lead to a high tungsten content and a high product yield. Due to the small particle size, applications in catalysis might be possible, although an industrial realization of the process seems unrealistic at moment.
\end{abstract}

Keywords Tungsten $\cdot$ Chemical vapour transport $\cdot$ Mechanism $\cdot$ Reduction $\cdot$ Nano-sized powder $\cdot \mathrm{WO}_{2}(\mathrm{OH})_{2}$

\section{Introduction}

Reduction of tungsten oxides by hydrogen is a well-established industrial process for the manufacture of well-defined and high-quality tungsten powder [1-7].

The overall reaction can be summarized by the chemical equation shown in Eq. (1).

$\mathrm{WO}_{3}+3 \mathrm{H}_{2} \rightleftharpoons \mathrm{W}+3 \mathrm{H}_{2} \mathrm{O}$.

In detail, the reduction is divided into several steps characterized by different intermediate oxides: $\mathrm{WO}_{3} \rightarrow \mathrm{WO}_{2.9} \rightarrow \mathrm{WO}_{2.72} \rightarrow \mathrm{WO}_{2} \rightarrow \mathrm{W}[1-4,8,9]$. The reaction rates at the different reduction steps are determined by the $\mathrm{H}_{2} \mathrm{O} / \mathrm{H}_{2}$ ratio in the vapour phase surrounding the oxide particles. At least the last three reduction steps are driven by chemical vapour transport (CVT) processes based on the formation of volatile $\mathrm{WO}_{2}(\mathrm{OH})_{2}[10,11]$. This

Roland Haubner

roland.haubner@tuwien.ac.at

1 TU Wien, A-1060 Vienna, Austria implies that every reduction step is split into two chemical reactions as shown in Eq. (2)-(4) for the formation of tungsten metal out of $\mathrm{WO}_{2}$ :

$\mathrm{WO}_{2}+2 \mathrm{H}_{2} \rightleftharpoons \mathrm{W}+2 \mathrm{H}_{2} \mathrm{O}$ (overall reaction),

$\mathrm{WO}_{2}+2 \mathrm{H}_{2} \mathrm{O} \rightleftharpoons \mathrm{WO}_{2}(\mathrm{OH})_{2}+\mathrm{H}_{2}$ (oxidation of $\mathrm{WO}_{2}$ by $\mathrm{H}_{2} \mathrm{O}$ ),

$\mathrm{WO}_{2}(\mathrm{OH})_{2}+3 \mathrm{H}_{2} \rightleftharpoons \mathrm{W}+4 \mathrm{H}_{2} \mathrm{O}$ (reduction by $\mathrm{H}_{2}$ after $\mathrm{CVT}$ ).

For industrial production, push-type or rotary furnaces are used to produce tungsten powders from coarse grained (up to $20 \mu \mathrm{m}$ ) to near-nano sized (down to $100 \mathrm{~nm}$ ). Because of the reduction in a bulk powder, the individual tungsten crystals are partly grown together and strongly agglomerated, which makes further processing into fine-crystalline WC difficult. The tungsten powder quality, in particular the particle size and size distribution, is strongly influenced by the local $\mathrm{H}_{2} \mathrm{O}$ concentration prevailing in the powder bed around the reacting particles [3]. The formation of gaseous $\mathrm{WO}_{2}(\mathrm{OH})_{2}$ from $\mathrm{WO}_{3}$ with water (see Eq. (5)) is known for 


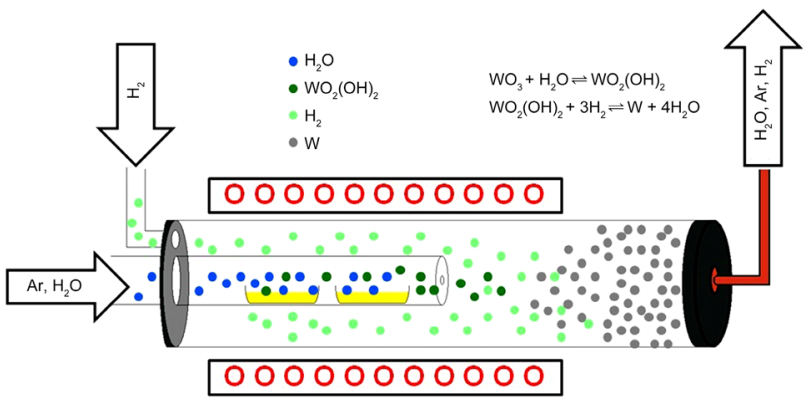

Fig. 1 Experimental setup for the production of nano-sized tungsten powder via the CVT reaction from $\mathrm{WO}_{3}$ (yellow material in quartz tube)

a long time and well described in literature [10-20]. The highest $\mathrm{WO}_{2}(\mathrm{OH})_{2}$ concentrations in the vapour phase (highest partial pressures) are obtained with $\mathrm{WO}_{3}$ and pure water vapour and high temperatures in equilibrium.

$\mathrm{WO}_{3}+\mathrm{H}_{2} \mathrm{O} \rightleftharpoons \mathrm{WO}_{2}(\mathrm{OH})_{2}(\mathrm{CVT}$ reaction $)$.

In this study, the approach is to generate $\mathrm{WO}_{2}(\mathrm{OH})_{2}$ via the CVT reaction and reduce it directly in the vapour phase to metallic $\mathrm{W}$ powder. Therefore, there needs to be a change in the conditions from generating the gaseous $\mathrm{WO}_{2}(\mathrm{OH})_{2}$ and the reduction zone. The approach should lead to the formation of tungsten powder with particle sizes in the lower nm range, with no intergrowths and low agglomeration, which are not achievable by the established industrial processes. Furthermore, the influence of the variation of parameters such as furnace temperature, temperature of the $\mathrm{H}_{2} \mathrm{O}$-bubbler and gas flows (hydrogen, argon), on the product yield and composition was investigated. However, only the results of the variation of the furnace temperature and temperature of the $\mathrm{H}_{2} \mathrm{O}$-bubbler are described in detail in this paper.

\section{Experimental}

The experimental equipment (Fig. 1) consisted of two concentric quartz tubes, which were externally heated by a Kanthal furnace. The smaller tube was connected with the bigger, outer tube by a hole at the end of the small tube. In the inner tube, two quartz boats filled with about $7 \mathrm{~g}$ of a $\mathrm{WO}_{3}$ powder each were placed. The $\mathrm{WO}_{3}$ powder was yellow (Fig. S1a) [21-23] and scanning electron microscopy (SEM) micrographs (Fig. S1b, c) showed the pseudomorphism to ammonium para tungstate (APT), which is an intermediate product of the tungsten refining process $[1,2]$. The humidity of argon was adjusted by leading the gas via a thermostatcontrolled water-filled container $\left(\mathrm{H}_{2} \mathrm{O}\right.$-bubbler) through the vapour pressure of water (Fig. S2). This humid argon was used to generate $\mathrm{WO}_{2}(\mathrm{OH})_{2}$ from the $\mathrm{WO}_{3}$ powder via the CVT reaction (Eq. 5). The $\mathrm{WO}_{2}(\mathrm{OH})_{2}$ was transported through a small hole into the outer quartz tube, where it got in contact with hydrogen, which was passed through the outer tube. The $\mathrm{W}$ powder formed was collected in the colder parts at the end of the outer quartz tube. Due to the fact that the reduction to $\mathrm{W}$ is driven by the $\mathrm{H}_{2} \mathrm{O} / \mathrm{H}_{2}$ ratio, it was necessary to find the right $\mathrm{H}_{2} \mathrm{O}$ concentrations in $\mathrm{Ar}$, which is high enough to evaporate $\mathrm{WO}_{3}$ and low enough to form $\mathrm{W}$ directly from the gas phase. Powder characterization was performed by X-ray diffraction (XRD), field emission scanning electron microscopy (FE-SEM) and transmission electron microscopy (TEM). The analysis of the electron diffraction patterns was carried out using "Gatan Microscopy Suite" of Gatan Inc. and the "PASAD Plug-In" of Christoph Gammer et al. [24].

\section{Results and discussion}

\section{1 $\mathrm{WO}_{2}(\mathrm{OH})_{2}$ evaporation from $\mathrm{WO}_{3}$}

First of all, the capability of the setup to transport $\mathrm{WO}_{3}$ via the CVT reaction from the inner to the outer tube was evaluated (Fig. 1). Therefore, three test series were executed: one at a constant temperature $\left(1150{ }^{\circ} \mathrm{C}\right)$ varying the Ar flow between 700 and $1200 \mathrm{~mL} \cdot \mathrm{min}^{-1}$ (Fig. S3a); a second one at constant Ar flow $\left(1200 \mathrm{~mL} \cdot \mathrm{min}^{-1}\right)$ varying the temperature between 1000 and $1150{ }^{\circ} \mathrm{C}$ (Fig. S3b); and a third one varying the $\mathrm{H}_{2} \mathrm{O}$-bubbler temperature (Fig. S3c).

As expected, increasing the Ar flow as well as the temperature increases the transported mass of $\mathrm{WO}_{3}$ indicating the use of the highest possible temperatures for an adequate tungsten transport.

By increasing the $\mathrm{H}_{2} \mathrm{O}$-bubbler temperature, the humidity of the argon gas overflowing the $\mathrm{WO}_{3}$ educt powder was varied between $35{ }^{\circ} \mathrm{C}(5.55 \%$ humidity $)$ and $50{ }^{\circ} \mathrm{C}(12.18 \%$ humidity). The other process parameters were fixed according to Table 1. Figure S3c illustrates the mass loss of the educt powder due to the evaporation process measured by differential weighing. With an increase in the $\mathrm{H}_{2} \mathrm{O}$-bubbler

Table 1 Parameters for the test series to vary the furnace temperature and the $\mathrm{H}_{2} \mathrm{O}$-bubbler temperature

\begin{tabular}{lll}
\hline & $\begin{array}{l}\text { Furnace temper- } \\
\text { ature variation }\end{array}$ & $\begin{array}{l}\mathrm{H}_{2} \mathrm{O} \text {-bubbler } \\
\text { temperature vari- } \\
\text { ation }\end{array}$ \\
\hline Furnace temperature $\left({ }^{\circ} \mathrm{C}\right)$ & $\mathbf{1 0 5 0 - 1 1 5 0}$ & 1100 \\
$\mathrm{H}_{2} \mathrm{O}$-bubbler temperature $\left({ }^{\circ} \mathrm{C}\right)$ & 50 & $\mathbf{3 5 - 5 0}$ \\
Ar gas flow $\left(\mathrm{mL} \cdot \mathrm{min}^{-1}\right)$ & 1000 & 1000 \\
$\mathrm{H}_{2}$ gas flow $\left(\mathrm{mL} \cdot \mathrm{min}^{-1}\right)$ & 700 & 1000 \\
duration $(\mathrm{h})$ & 2 & 2 \\
\hline
\end{tabular}




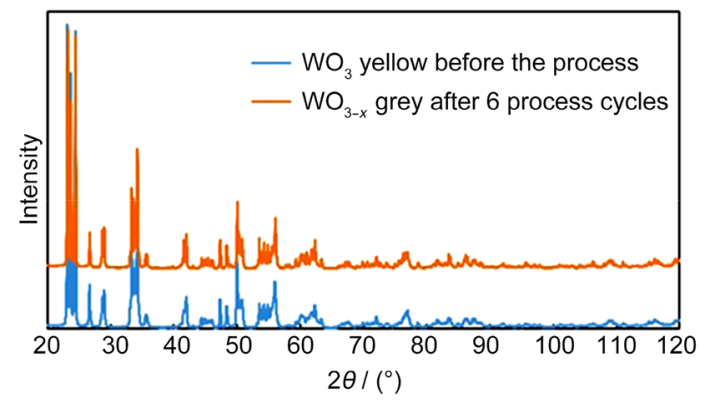

Fig. 2 XRD patterns of the $\mathrm{WO}_{3}$ educt powder before the process (blue) and $\mathrm{WO}_{3-x}$ after six process cycles (orange)

temperature, an increase in the $\mathrm{WO}_{3}$ evaporation rate is also observed. This is due to increased air humidity and thus to a shift in the evaporation reaction towards the $\mathrm{WO}_{2}(\mathrm{OH})_{2}$ side.

The particle sizes of deposited $\mathrm{WO}_{3}$ powders are shown in the nanometer region (Fig. S4).

\subsection{Changes of the $\mathrm{WO}_{3}$ educt powder during $\mathrm{WO}_{2}(\mathrm{OH})_{2}$ evaporation}

After multiple evaporation cycles, the yellow greenish educt powder turned bluish black (Fig. S5). Despite the change of colour, the XRD patterns of the original powder and the powder after six process cycles match each other accurately. The change of colour is due to a slight loss of oxygen of the $\mathrm{WO}_{3}$ during the process [1]. This crystallographic shear structure $\left(\mathrm{WO}_{3-x}\right)$ has no visible influence on the XRD pattern (Fig. 2). In the SEM micrographs (Fig. S6), differences in morphology are visible. The starting powder (Fig. S6a, b) consists of porous prismatic agglomerates made of fine $\mathrm{WO}_{3}$, with a particle size of approximately $30 \mu \mathrm{m}$. After six process cycles (Fig. S6c, d), the $\mathrm{WO}_{3-x}$ powder is recrystallized and consists of faceted single crystals that have grown together to form larger agglomerates. The size of these individual crystals is about $30 \mu \mathrm{m}$ and the agglomerates are up to $200 \mu \mathrm{m}$ large. This recrystallization is due to the production of gaseous $\mathrm{WO}_{2}(\mathrm{OH})_{2}$, which is a short transport of the hydroxide and redeposition. Hence due to this recrystallization of $\mathrm{WO}_{3-\mathrm{x}}$ and decrease of the powder surface, no significant decrease in the evaporation rate over several cycles is observable.

\subsection{Influence of the furnace temperature on the $\mathrm{WO}_{2}(\mathrm{OH})_{2}$ evaporation and tungsten formation}

In this test series, the furnace temperature was varied between 1050 and $1150{ }^{\circ} \mathrm{C}$, leaving the other process parameters fixed at the values shown in Table 1. In Fig. 3, the achieved $\mathrm{W}$-powder yield at different furnace temperatures

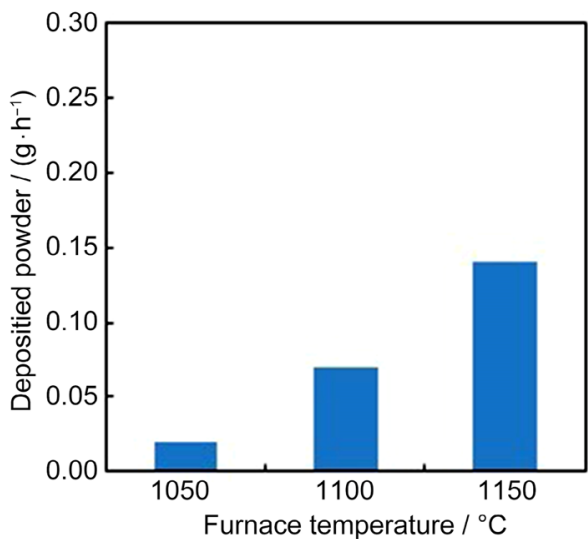

Fig. 3 Product powder yield at different furnace temperatures $\left(50{ }^{\circ} \mathrm{C}\right.$ $\mathrm{H}_{2} \mathrm{O}$-bubbler, gas flows: $1000 \mathrm{~mL} \cdot \mathrm{min}^{-1} \mathrm{Ar}, 700 \mathrm{~mL} \cdot \mathrm{min}^{-1} \mathrm{H}_{2}$ )

is illustrated. With an increase in the furnace temperature, an increase in the powder yield occurs. Due to the higher furnace temperature, the equilibrium of the CVT-reaction is shifted to the side of $\mathrm{WO}_{2}(\mathrm{OH})_{2}$, leading to a higher evaporation rate and therefore a higher product powder yield. The increase of the tungsten transport via higher temperature is also shown in literature by Glemser et al. [11, 14] and Matviichuk et al. [15].

In Fig. 4, FE-SEM micrographs of the different product powders are shown. At $1050{ }^{\circ} \mathrm{C}$, the particle size is about $80 \mathrm{~nm}$, and it is about $110 \mathrm{~nm}$ at $1150{ }^{\circ} \mathrm{C}$. An increase in the grain size is visible with increasing furnace temperature, but due to the insufficient resolution of the FE-SEM, it is not visible whether the particles are single crystals or agglomerates.

Figure 5 shows the composition of each product powder measured by XRD and calculated by Rietveld analysis. The powders consist mainly of $\mathrm{WO}_{3}$ with small amounts of $\mathrm{WO}_{2}$. The desired $\mathrm{W}$ phase makes up only 9.6-16.8 at\% of the powder. The amount of the metallic $\mathrm{W}$ phase increases with increasing the furnace temperature, because higher temperatures favour the reduction process. The results show that the $\mathrm{H}_{2} \mathrm{O}$ concentration in the reaction zone was too high to reach an $\mathrm{H}_{2} \mathrm{O} / \mathrm{H}_{2}$ ratio forming pure $\mathrm{W}$.

\subsection{Influence of the variation of the $\mathrm{H}_{2} \mathrm{O}$-bubbler temperature on $\mathrm{W}$ formation}

The $\mathrm{H}_{2} \mathrm{O}$-bubbler temperature was varied between 35 and $50{ }^{\circ} \mathrm{C}$ fixing the other process parameters according to Table 1.

The mass of the product powder at different $\mathrm{H}_{2} \mathrm{O}$-bubbler temperatures is shown in Fig. 6. The mass of the evaporated oxide has already been shown in Fig. S3c. Increasing humidity increases the transport process and therefore leads to a higher evaporation rate and consequently a higher product 

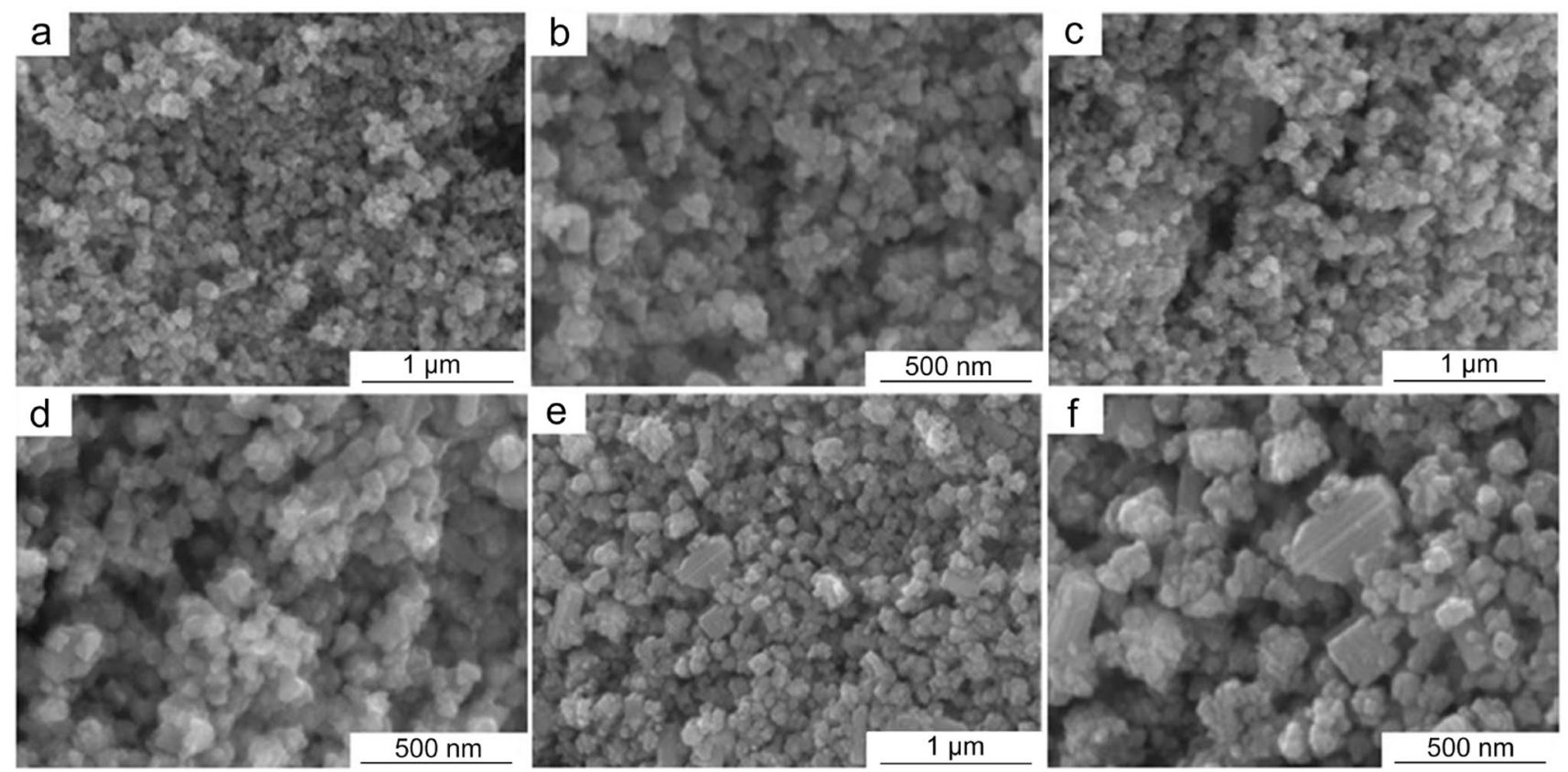

Fig. $4 \mathrm{~W}-\mathrm{WO}_{x}$ deposits formed at different furnace temperatures: a, b $1050{ }^{\circ} \mathrm{C}, \mathbf{c}, \mathbf{d} 1100{ }^{\circ} \mathrm{C}, \mathbf{e}, \mathbf{f} 1150{ }^{\circ} \mathrm{C}$

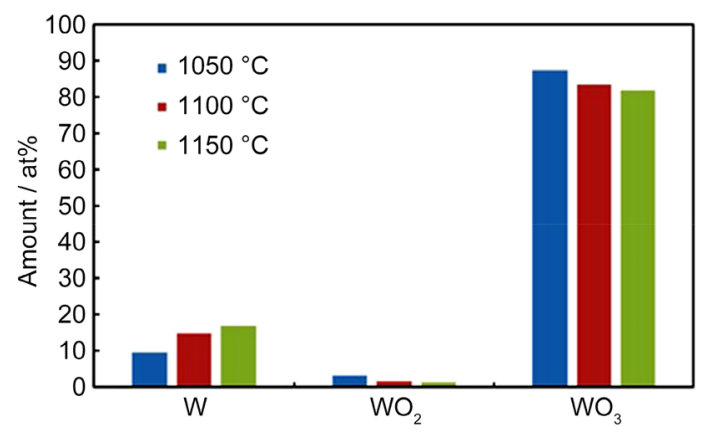

Fig. 5 Variation of the furnace temperature: composition of the deposited powders produced at different temperatures (by Rietveld analysis)

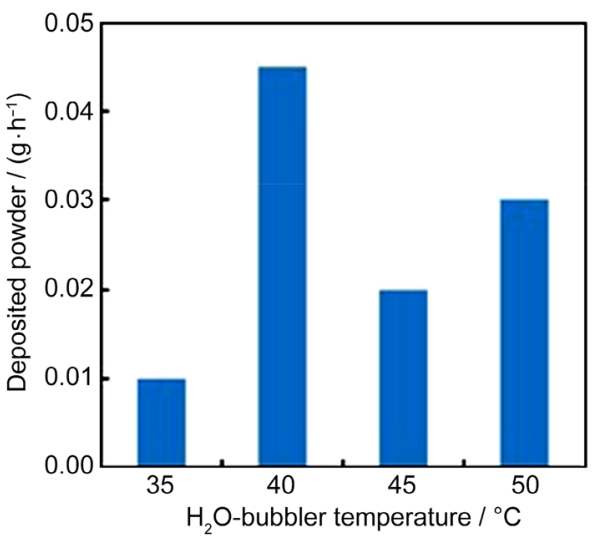

Fig. 6 Product powder yield at different $\mathrm{H}_{2} \mathrm{O}$-bubbler temperatures (furnace temperature $1100{ }^{\circ} \mathrm{C}$, gas flows: $1000 \mathrm{~mL} \cdot \mathrm{min}^{-1} \mathrm{Ar}$, $\left.1000 \mathrm{~mL} \cdot \mathrm{min}^{-1} \mathrm{H}_{2}\right)$ powder yield. The discrepancy between the mass of powder, which is evaporated, and the mass of the product is on one side due to the lower molecular weight of the metallic phase compared with the oxide and on the other side due to several losses because of inaccessible depositions (e.g. in the exhaust pipe).
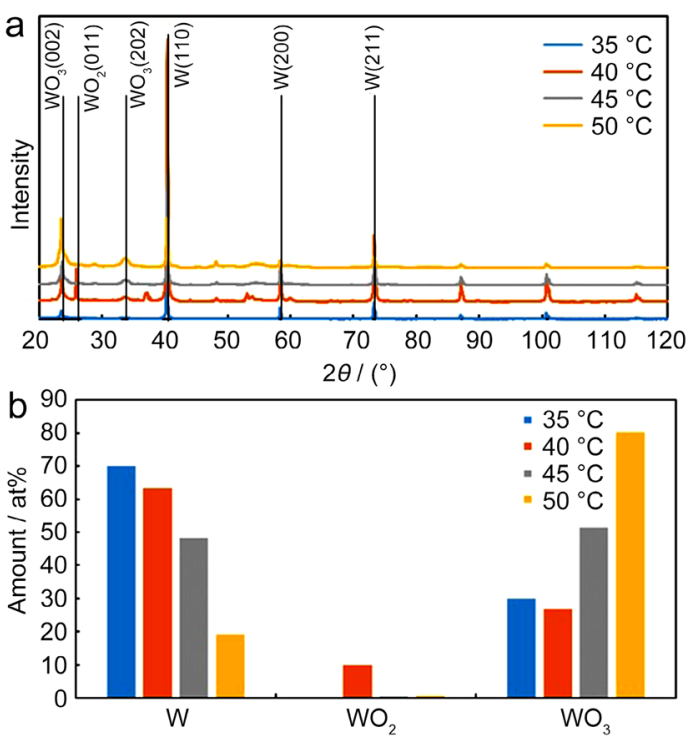

Fig. 7 Variation of the $\mathrm{H}_{2} \mathrm{O}$-bubbler temperature: a XRD pattern, b composition of the powders produced at different $\mathrm{H}_{2} \mathrm{O}$-bubbler temperatures (by Rietveld analysis) 
Figure 7a shows the XRD patterns of the different product powders. With decreasing $\mathrm{H}_{2} \mathrm{O}$-bubbler temperature, decreasing intensities of the oxide reflexes are observed. Figure $7 \mathrm{~b}$ illustrates the composition of the powders produced at different $\mathrm{H}_{2} \mathrm{O}$-bubbler temperatures calculated by Rietveld analysis. The amount of oxide phases decreases with a decreasing $\mathrm{H}_{2} \mathrm{O}$-bubbler temperature and thereby a decreasing humidity. In contrast, the amount of metallic tungsten phase increases up to 70 at $\%$ due to the increase of the reduction power (depending on the $\mathrm{H}_{2} / \mathrm{H}_{2} \mathrm{O}$ ratio) with a decrease of humidity. It is also visible in Eq. (4) that a decrease in the $\mathrm{H}_{2} \mathrm{O}$ concentration shifts the reaction equilibrium to the product. As temperature decreases in the deposition zone, possible reoxidation of already reduced tungsten to $\mathrm{WO}_{\mathrm{x}}$ at constant water vapour has to be taken in account.
To avoid these reverse reactions, the entire collection area of the powder has to be kept at around $1000{ }^{\circ} \mathrm{C}$, which was not possible with the present experimental reactor.

The sample produced at $35^{\circ} \mathrm{C}_{2} \mathrm{O}$-bubbler temperature was characterized by TEM and electron diffraction (Fig. 8). The TEM micrographs show two kinds of crystallite shapes (Fig. 8a).

On the one side, there are rounded particles with a size of 8-20 nm (Fig. 8b) and on the other side there are rod-shaped crystallites with a length of about $120-150 \mathrm{~nm}$ (Fig. 8b, c). The different shapes can be explained by the mixture of tungsten and $\mathrm{WO}_{x}$. Regarding the morphology, the rodshaped crystallites resemble $\mathrm{WO}_{3-x}$, which occurs during the reduction of $\mathrm{WO}_{3}$ with hydrogen $[3,9]$. The electron diffraction pattern of the powder (Fig. 8d) includes the patterns of
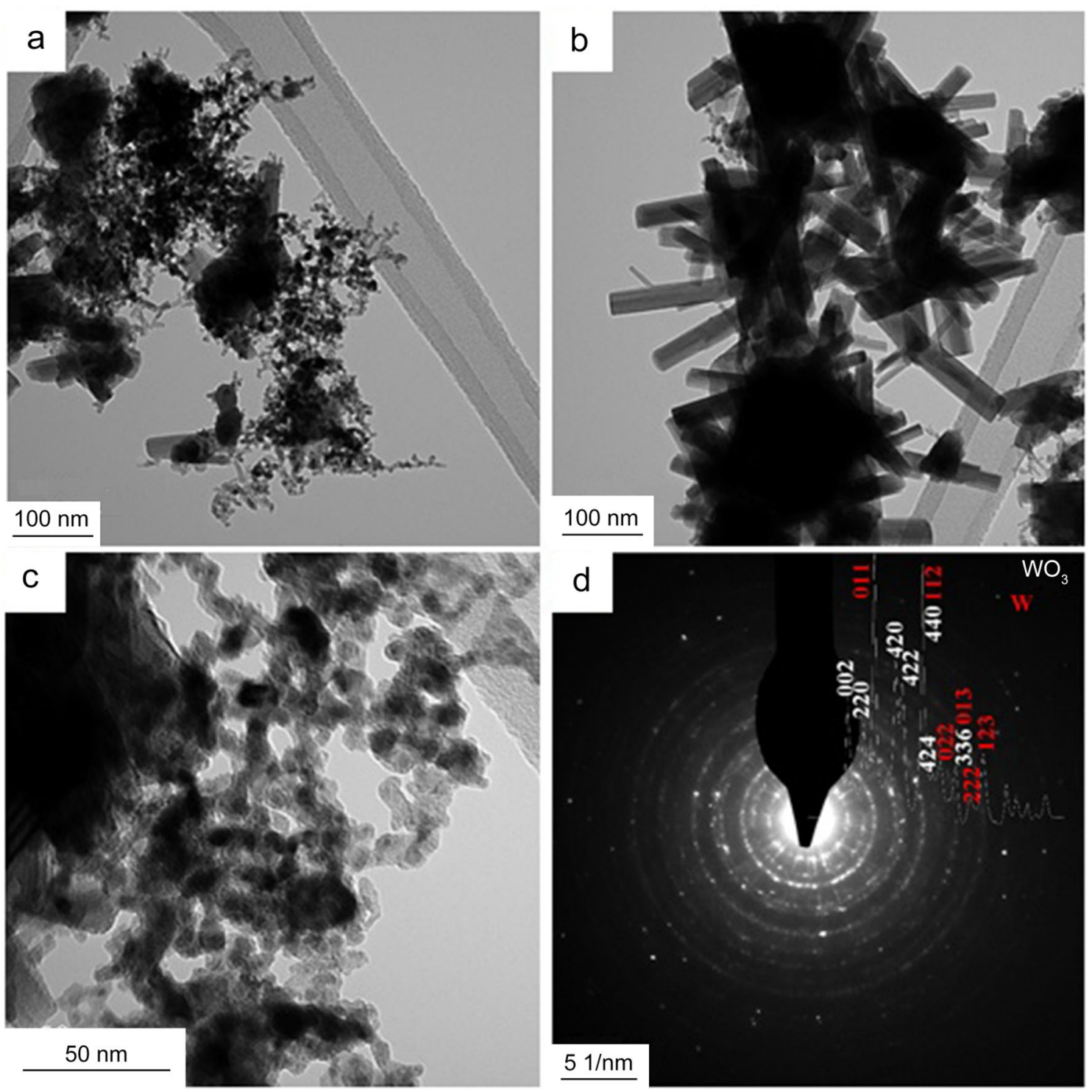

Fig. 8 a-c TEM micrographs and $\mathbf{d}$ electron diffraction pattern of powder produced at a $\mathrm{H}_{2} \mathrm{O}$-bubbler temperature of $35^{\circ} \mathrm{C}$ 
both phases, metallic $\mathrm{W}$ and $\mathrm{WO}_{3}$ which corresponds to the results of the XRD analysis. The rounded particles seem to be $\mathrm{W}-\mathrm{WO}_{x}$, which reach the deposition zone partially unreduced. The rod-shaped crystallites seem to have a common centre, which could be a nucleus on which the tungsten/ tungsten oxide rods are deposited out of the gas phase.

\subsection{Variation of the gas flows}

The variation of the hydrogen and argon flow rates are not shown in detail in this paper, but shown in the diploma thesis of Dalbauer [25]. The hydrogen flow rate has no significant influence on the transport process, but is crucial to the composition of the product because of the resulting $\mathrm{H}_{2} / \mathrm{H}_{2} \mathrm{O}$ ratio. The argon flow rate has an influence on the process which is similar to the $\mathrm{H}_{2} \mathrm{O}$-bubbler temperature but to a smaller extent.

\section{Summary}

With the combination of the CVT reaction and a reduction with $\mathrm{H}_{2}$, it is possible to produce tungsten powder with particle sizes of about $100 \mathrm{~nm}$. However, due to the required humidity for the CVT process, the reduction was partially incomplete and thereby oxidic residues $\left(\mathrm{WO}_{3-x}\right)$ were present in the product, which would be problematic for industrial applications.

By optimizing the process parameters, the powder yield and also the amount of metallic tungsten in the product could be increased. Elevated furnace temperatures, like $1200{ }^{\circ} \mathrm{C}$ and beyond, and further optimization of the humidity and the gas flows could provide positive effects on the process. Another possibility for improving the process could be the implementation of flow breakers in the deposition zone. This should result in a higher deposition rate and an increased powder yield. A further improvement of the process could be the usage of a $\mathrm{CH}_{4} / \mathrm{H}_{2}$ mixture as reaction gas to produce nano-sized WC powder. Due to the small particle sizes, the powder may be of interest to applications in catalysis although an industrial realization of the process is at the moment unrealistic.

Supplementary Information The online version contains supplementary material available at https://doi.org/10.1007/s42864-021-00118-1.

Acknowledgements Facilities at the University Service Centre for Transmission Electron Microscopy (TU Wien, Austria) were used to carry out the FE-SEM and TEM measurements.

Author contributions MO and VD collected the data. W-DS and RH contributed to conceiving the idea of the study. MO, W-DS and RH contributed to the writing and revisions.
Funding Open access funding provided by TU Wien (TUW).

\section{Declarations}

Conflict of interest The authors declare no conflict of interest.

Open Access This article is licensed under a Creative Commons Attribution 4.0 International License, which permits use, sharing, adaptation, distribution and reproduction in any medium or format, as long as you give appropriate credit to the original author(s) and the source, provide a link to the Creative Commons licence, and indicate if changes were made. The images or other third party material in this article are included in the article's Creative Commons licence, unless indicated otherwise in a credit line to the material. If material is not included in the article's Creative Commons licence and your intended use is not permitted by statutory regulation or exceeds the permitted use, you will need to obtain permission directly from the copyright holder. To view a copy of this licence, visit http://creativecommons.org/licenses/by/4.0/.

\section{References}

1. Lassner E, Schubert WD. Tungsten: properties, chemistry, technology of the element, alloys, and chemical compounds. New York: Kluwer Academic; 1999.

2. Wilken TR, Morcom WR, Wert CA, Woodhouse JB. Reduction of tungsten oxide to tungsten metal. Metall Trans B. 1976;7:589.

3. Haubner R, Schubert WD, Lassner E, Schreiner M, Lux B. Mechanical of technical reduction of tungsten: part 1 literature review. Int J Refract Metal Hard Mater. 1983;3:108.

4. Haubner R, Schubert WD, Hellmer H, Lassner E, Lux B. Mechanical of technical reduction of tungsten: part 2 hydrogen reduction of tungsten blue oxide to tungsten powder. Int J Refract Metal Hard Mater. 1983;4:156.

5. Haubner R, Schubert WD, Hellmer H, Lassner E, Lux B. Thermodynamic and kinetic considerations on technical hydrogen reduction of tungsten blue oxide to tungsten powder. Adv Hard Mater Hard Metal Prod. 1983;2:1.

6. Zhiqiang Z, Enxi W, Aichun T, Chungliang Q. Formation of tungsten blue oxide and its hydrogen reduction. In: 11 th International Plansee Seminar'85 1985;1:337.

7. Hellmer H, Schubert W-D, Lassner E, Lux B. Kinetik der Wolframreduktion. In: 11th International Plansee Seminar' 85. 1985:3;43.

8. Venables DS, Brown ME. Reduction of tungsten oxides with hydrogen and with hydrogen and carbon. Thermochim Acta. 1997;291:131.

9. Choain C, Marion F. Sur les équilibres d'oxydoréduction des oxydes de tungstène. Comptes rendus hebdomadaires des séances de l'Académie des sciences 1961:3258.

10. Haubner R, Schubert W-D, Hellmer H, Lassner E, Lux B. Die Wolframreduktion. In: 11th International Plansee Seminar' 85. 1985;2:161.

11. Glemser $\mathrm{O}$, Ackermann H. Ergänzende Untersuchungen über gasförmiges $\mathrm{WO}_{2}(\mathrm{OH})_{2}$. Z Anorg Allg Chem. 1963;325:281.

12. Meyer G, Oosterom JF, van Oeveren WJ. The vapour pressure of tungsten trioxide in gas mixtures containing water vapour. Recl Trav Chim Pays-Bas. 1959;78:417.

13. Belton GR, McCarron RL. The volatilization of tungsten in the presence of water vapor. J Phys Chem. 1964;68:1852.

14. Wang S, He Y, Fang X, Zou J, Wang Y, Huang H, et al. Structure and field-emission properties of sub-micrometer-sized tungsten-whisker arrays fabricated by vapor deposition. Adv Mater. 2009;21:2387. 
15. Millner T, Neugebauer J. Volatility of the oxides of tungsten and molybdenum in the presence of water vapour. Nature. 1949;163:601.

16. Glemser O, Haeseler RV. Über gasförmige Hydroxide des Molybdäns und Wolframs. Z Anorg Allg Chem. 1962;316:168.

17. Glemser $\mathrm{O}$, Völz HG. Über gasförmiges $\mathrm{WO}_{2}(\mathrm{OH})_{2}$. Naturwissenschaften. 1956;43:33.

18. Blackburn PE, Hoch M, Johnston HL. The vaporization of molybdenum and tungsten oxides. J Phys Chem. 1958;62:769.

19. Glemser O, Wendlandt HG. Gaseous hydroxides. In: Advances in inorganic chemistry and radiochemistry, vol. 5. Elsevier; 1963. p. 215.

20. Matviichuk OO, Bondarenko VP, Galkov AV, Ievdokymova OV. Kinetics of transport of $\mathrm{WO}_{3}$ via gas phase. In: 4th International Samsonov Memorial Conference. Kyiv, Ukraine; 2014.

21. Weil M, Schubert W-D. The beautiful colours of tungsten oxides. ITIA Newslett 2013;1.
22. Diehl R, Brandt G, Salje E. The crystal structure of triclinic $\mathrm{WO}_{3}$. Acta Crystallogr B Struct Sci. 1978;34:1105.

23. Tilley RJD. The crystal chemistry of the higher tungsten oxides. In: The Chemistry of non-sag tungsten. Elsevier; 1995. p. 93.

24. Gammer C, Mangler C, Rentenberger C, Karnthaler HP. Quantitative local profile analysis of nanomaterials by electron diffraction. Scripta Mater. 2010;63:312.

25. Dalbauer V. Herstellung von sehr feinem und sehr grobem Wolframmetallpulver. Diploma Thesis. TU Wien; 2015.

Publisher's Note Springer Nature remains neutral with regard to jurisdictional claims in published maps and institutional affiliations. 